CLINICAL STUDY

\title{
Aryl hydrocarbon receptor-interacting protein and pituitary adenomas: a population-based study on subjects exposed to dioxin after the Seveso, Italy, accident
}

\author{
Angela Cecilia Pesatori ${ }^{1,2}$, Andrea Baccarelli ${ }^{2,3}$, Dario Consonni ${ }^{2}$, Andrea Lania ${ }^{4}$, Paolo Beck-Peccoz ${ }^{4}$, \\ Pier Alberto Bertazzi ${ }^{1,2}$ and Anna Spada ${ }^{4}$ \\ ${ }^{1}$ Department of Occupational and Environmental Health, EPOCA Research Center, Clinica 'L Devoto', University of Milan, Via San Barnaba 8,20122 \\ Milano, Italy, ${ }^{2}$ Epidemiology Unit, Department of Preventive Medicine, Fondazione IRCCS Ospedale Maggiore Policlinico, Mangiagalli e Regina Elena, \\ Milan, Italy, ${ }^{3}$ Department of Occupational and Environmental Health, Center of Molecular and Genetic Epidemiology, University of Milan, Milan, Italy and \\ ${ }^{4}$ Endocrine Unit, Department of Medical Sciences, Fondazione IRCCS Ospedale Maggiore Policlinico, Mangiagalli e Regina Elena, University of Milan, \\ Milan, Italy \\ (Correspondence should be addressed to A C Pesatori; Email: angela.pesatori@uninimi.it)
}

\begin{abstract}
Objective: The pathogenesis of sporadic pituitary tumors is unknown. Loss-of-function mutations of aryl hydrocarbon receptor-interacting protein (AIP) have been identified in patients with familial pituitary tumors. AIP is a chaperone protein with multifunction properties, including modulation of the transcriptional activity of the aryl hydrocarbon receptor, which mediates toxicological and carcinogenic dioxin effects.

Design: We investigated the incidence of pituitary tumors in the Seveso population exposed to 2,3,7,8tetrachlorodibenzo-para-dioxin following an industrial accident in 1976.

Methods: Through the hospital discharge registration system of Lombardy Region, we identified incident cases of pituitary adenomas between 1976 and 1996 in the Seveso population, subdivided in zone A $(n=804), \mathrm{B}(n=5.941)$, and $\mathrm{R}(n=38.624)$ according to high, intermediate, and low exposure to dioxin respectively, and in the surrounding non-contaminated area, as reference $(n=232745)$. Results: We identified 42 pituitary adenomas in the reference area, 1 prolactinoma in zone A (rate ratio (RR) 6.2; 95\% CI 0.9-45.5, $P=0.07$ ), 2 nonfuctioning pituitary tumors (NFPAs) in zone B (RR 1.9; 95\% CI $0.5-7.7, P=0.39$ ), and 3 prolactinomas and 2 NFPAs in zone R (RR 0.7; 95\% CI 0.3-1.8, $P=0.48$ ). Conclusions: The study is unique with regard to the availability of epidemiological and clinical data in an area of relatively pure dioxin exposure. The study indicates no statistically significant increase of incident pituitary tumors in this area, although the tendency toward a higher risk (three cases in zones A and B) of pituitary tumors in subjects exposed to high-intermediate dioxin concentrations in comparison with nonexposed population suggests the need for extended follow-up.
\end{abstract}

European Journal of Endocrinology 159 699-703

\section{Introduction}

Pituitary tumors are benign lesions that account for substantial morbidity due to hormone over-production and/or intracranial mass effects. Despite the large number of mutational studies carried out in the past decades, the pathogenesis of these tumors remains largely unknown (1). Vierimaa et al. recently reported loss-of-function mutations of the gene encoding the aryl hydrocarbon receptor-interacting protein (AIP) in patients with familial pituitary tumors, suggesting that AIP may operate as a tumor suppressor gene determining pituitary tumor susceptibility (2). This hypothesis has been recently confirmed by in vitro data showing a reduced ability of mutant AIP to block cell proliferation (3).

Clinical characterization of patients with familial isolated pituitary adenomas associated with AIP mutations reported a relative predominance of somatotropinomas, with a low incidence of prolactinomas and nonfuctioning pituitary adenomas, an early age at diagnosis, and a particularly aggressive tumor behavior $(3,4)$. In contrast to the frequency of AIP mutations in familial isolated pituitary tumors, evaluated in $~ 15 \%$, screening studies failed to detect AIP mutations in most sporadic pituitary adenomas (5).

AIP is a chaperone protein that interacts with several partners, including the aryl hydrocarbon receptor (AHR), an orphan nuclear receptor that is strongly activated by 2,3,7,8-tetrachlorodibenzo-p-dioxin (TCDD or simply dioxin) and mediates dioxin toxicological properties (6). In particular, AIP modulates the function of AHR by both protecting AHR from ubiquitination or retaining AHR in the cytoplasm and preventing transcriptional activity $(7,8)$. Although these data 
suggest that AIP inactivation might result in AHR signaling amplification, whether exposure to dioxin increases the risk of pituitary adenomas has never been determined. An industrial accident in Seveso, Italy, in 1976 exposed thousands of people to substantial quantities of dioxin. Mortality and morbidity findings during the 20-25-year period following the accident showed increased risk from cancers, particularly lymphoemopoietic neoplasms (9-11).

The aim of the study was to evaluate the impact of exposure to dioxin on the incidence of pituitary tumors in the Seveso population.

\section{Materials and methods}

\section{Subjects}

Immediately after the accident, three areas of high, intermediate, and low contamination (zone A, B, and R respectively) were delimited on the basis of soil dioxin measurements (Fig. 1A). A surrounding non-contaminated territory was adopted as reference area. Subjects were assigned to one of the contaminated zones or the reference area on the basis of their residence at the date

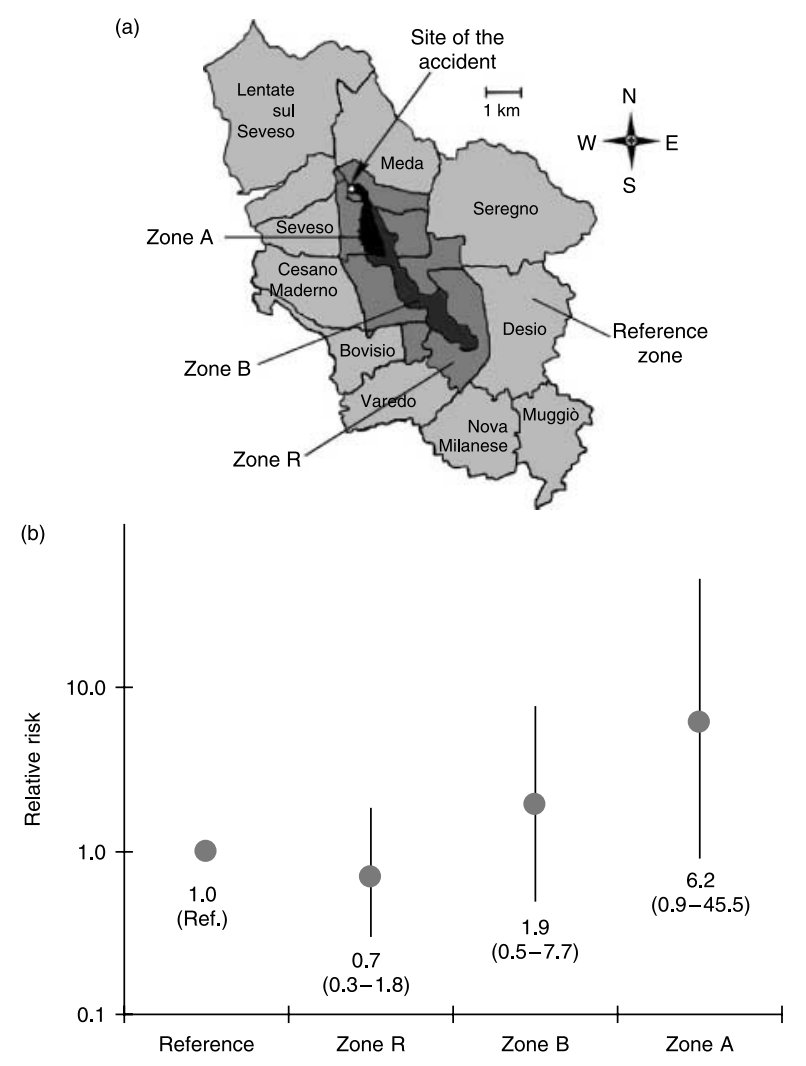

Figure 1 (a) Map of the Seveso area. The map shows the three contaminated zones with decreasing TCDD soil levels (A, B, and R) and the surrounding non-contaminated zone adopted as reference. (b) Age-gender-calendar period-adjusted relative risks and 95\% confidence intervals for pituitary tumors across exposure zones. of the accident. Improvements in analytical techniques allowed the measurement of TCDD levels in very small blood samples collected at the time of the accident among subjects chosen as the most highly exposed in zone A, B, and R $(12,13)$. Serum TCDD levels, measured on blood samples taken at the time of the accident (13), showed that contamination zones correctly represented three levels of decreasing exposure to dioxin (Table 1). Median levels in a random sample of subjects from the reference nonexposed area were $5.5 \mathrm{ppt}$, representing the typical value in the general population (14). A cross-sectional study conducted $\sim 20$ years after the accident on subjects from zones $A$ and $B$ showed persisting elevated levels of serum TCDD, as expected based on the long ( $>7$ years) TCDD half-life $(14,15)$. All subjects living in the Seveso area were followed up, blind of their exposure status, to evaluate long-term health effects through mortality and cancer incidence studies $(9,11)$. Incident cases of pituitary adenoma between 1976 and 1996 were identified through the hospital discharge registration system of the Lombardy Region (where the study area is located). For each case, all relevant medical records were reviewed and diagnoses confirmed.

\section{Statistical analysis}

Rate ratios (RR) and 95\% confidence intervals (CI) were estimated with Poisson regression techniques controlling for age, gender, and calendar period, assuming a 10-year latency for dioxin effects. The surrounding noncontaminated area was used as reference. The results reported here refer to subjects, aged 0-74 years, resident in the accident area at the time of the accident (July 10, 1976).

\section{Results}

Characteristics of pituitary adenoma cases diagnosed in the Seveso population are summarized in Table 1. Assuming a 10-year latency for dioxin effects after the 1976 accident, eight tumors were identified between 1986 and 1996. In particular, one case of microprolactinoma was diagnosed in a 33-year-old woman living in the most contaminated zone (zone A, 804 subjects) at the time of the accident. Interestingly, soon after the accident she developed chloracne, the typical skin disorder due to exposure to dioxin-like compounds. In 1997, this subject was involved in a study designed to investigate health status and serum dioxin levels in chloracne cases (15), which showed that her serum TCDD was still very elevated (231 ppt). Two nonfunctioning pituitary adenoma (NFPA) were diagnosed among subjects present in zone B $(n=5.941)$ and five (three prolactinomas and two NFPA) in zone $\mathrm{R}$ $(n=38.624)$. Age-, sex-, and period-adjusted relative risks (RRs) indicated no statistically significant increase 
Table 1 Characteristics of pituitary adenoma cases diagnosed between 1976 and 1996 in the Seveso population.

\begin{tabular}{|c|c|c|c|c|c|}
\hline Exposure zone & Median serum dioxin levels (ppt) & Gender & Age at diagnosis (years) & Year of diagnosis & Tumor type \\
\hline Zone A $N=804$ & 447 & Female $^{\mathrm{b}}$ & 33 & 1993 & PRL-oma \\
\hline \multirow{2}{*}{ Zone B $N=5941$} & 94 & Female & 55 & 1993 & NFPA \\
\hline & & Male & 47 & 1986 & NFPA \\
\hline \multirow[t]{5}{*}{ Zone R N=38 624} & 48 & Female & 22 & 1996 & PRL-oma \\
\hline & & Female & 16 & 1990 & PRL-oma \\
\hline & & Female & 48 & 1990 & NFPA \\
\hline & & Male & 71 & 1994 & NFPA \\
\hline & & Male & 47 & 1995 & PRL-oma \\
\hline
\end{tabular}

PRL-oma, prolactin secreting adenoma; NFPA, nonfunctioning pituitary adenoma.

${ }^{\text {a } T e t r a c h l o r o d i b e n z o-p-d i o x i n ~(p a r t s ~ p e r ~ t r i l l i o n, ~ p p t) ~ m e a s u r e d ~ i n ~ s e r u m ~ s a m p l e s ~ c o l l e c t e d ~ b e t w e e n ~} 1977$ and 1978 from subjects present at the accident in the contaminated zones.

bubject who developed chloracne after the accident.

in pituitary adenoma incidence in subjects exposed to high and intermediate concentrations of dioxin in comparison with the nonexposed reference population (42 cases per 232.745 population). However, a tendency toward a higher risk of pituitary tumors in zones A and B with RRs of 6.2 (95\% CI 0.9-45.5, $P=0.07)$ and $1.9(95 \%$ CI $0.5-7.7, P=0.39)$ respectively, was observed (Fig. 1B). The incidence of pituitary tumors in the least contaminated area (zone R) did not differ from the reference population $(\mathrm{RR}=0.7 ; 95 \% \mathrm{CI}$ $0.3-1.8, P=0.48)$.

\section{Discussion}

This study first reports the incidence of pituitary tumors in an area of relatively pure exposure to TCDD. TCDD is the most toxic member of the large family of polychlorodibenzodioxins, which was recognized as a strong toxicant and carcinogen in experimental animals. Studies of military and occupational cohorts have led to the classification of TCDD as a human carcinogen (16). The Seveso accident in 1976 caused severe TCDD exposure to a population comprising of both genders and all ages, with little or no interference by other contaminants. In the early post-accident period, several health outcomes, such as spontaneous abortion, cytogenetic abnormalities, congenital malformations, liver function, immunological and neurological impairment, and chloracne, were evaluated (11). Cohort studies that investigated the long-term impact of the accident recorded elevated risk of lymphatic and hematopoietic neoplasm, increased cardiovascular mortality in the first years after the event, and suggestive increases in diabetes and chronic lung diseases (9-11).

Several recent studies reported that patients with familial pituitary adenomas frequently carry loss-of-function mutations of AIP, a chaperone protein that, among several other functions, modulates AHR transcriptional activity (2). In the present study, we tested the hypothesis that the direct activation of AHR by carcinogens might result in increased risk of pituitary adenoma development. The study indicates no statistically significant increase in the prevalence of the disease due to the massive exposure to TCCD. We are confident that the study was not affected by major selection bias, although the small population size for this particular tumor type is an obvious study limitation. First, zone categorization received support from results on blood dioxin measurements, which clearly indicated that there was a definite dose gradient $A>B>R(13,14)$. Interestingly, the patient with prolactinoma in zone $A$ was one of the 182 subjects who developed chloracne, the typical skin disorder due to halogenated hydrocarbon compounds, which was associated with very intense exposures to dioxin in the Seveso population (17). Secondly, since the exposed and reference populations belonged to the same health districts and had similar access to the same health services, differences in the hospital discharge registration were not expected. Finally, all the follow-up procedures, including confirmation of the original medical records by an experienced physician, were performed blindly with regard to the residence of the subjects. However, due to the relatively poor clinical manifestations and the slow progression of the disease, it is very likely that the incidence of pituitary tumors has been underestimated, but the degree of diagnostic inaccuracy is expected to be similar in the exposed and reference populations. In this respect, recent studies reported a prevalence of pituitary tumors higher than that observed in the reference population of the present study. In fact, the prevalence in the non-contaminated area (18 cases per 100.000) was similar to that reported by Davis et al. (18) in a study of the Stoke-on-Trent region (UK) between 1988 and 1998 (19-28 cases per 100.000), but definitely lower than that reported by Daly et al. (19) in a crosssectional study in the province of Liege, Belgium (94 cases per 100.000), this increase being very likely related to the intensive case finding approach and active surveillance of local medical practitioners used in that study (19).

Previous studies reported increased incidence of pituitary adenomas during the last decades. In particular, a Swedish Cancer Registry study reported the 
doubling of incidence of pituitary adenomas in 1991 in comparison with the previous data in 1958 (20). It is unknown whether this rise in incidence was due to access to better diagnostic techniques, increased medical awareness, environmental toxins and disruptors, or a combination of these factors. The present results do not provide evidence for a major role of specific environmental carcinogens, such as dioxin, polycyclic aromatic hydrocarbons, and polychlorinated biphenyls, in increased incidence of pituitary tumors. However, our study showed a tendency toward an elevated risk of developing pituitary tumors in the most polluted zone $\mathrm{A}$ and in the zone of intermediate pollution (zone B) in comparison with the nonexposed reference population. This trend (although based on only three cases) deserves some considerations. First, it is likely that this tendency did not reach statistical significance due to the limited number of exposed subjects and the low incidence of pituitary tumors in the general population. Moreover, the study was a longitudinal study conducted $\sim 20$ years after the accident, a latency that was appropriate for the development of diseases with high proliferative potential, such as lung, digestive, lymphatic, and hematopoietic cancers (9). However, considering the indolent nature of pituitary adenomas, this period of observation might still be inadequate. Extended follow-up of pituitary tumor incidence in the Seveso cohort is ongoing.

Pituitary tumors observed in the polluted zones were prolactinomas and NFPAs, while it is well established that AIP mutations are present in families with somatotroph adenomas, in families with both somatotroph and lactotroph adenomas and rarely in families with other types of pituitary tumors (2-4). This difference may be due to either the lack of correlation between exposure to dioxin and pituitary adenoma development or, alternatively, to the multiplicity of proteins, other than AHR, that interact with AIP. In particular, it has been recently demonstrated that naturally occurring AIP mutations lead to disrupted interaction between AIP and phosphodiesterase-4A5, resulting in deregulation of cAMP degradation $(3,21)$. Since cAMP is a proliferative signal for somatotrophs and not for the other pituitary cell lineages (22), it is tempting to speculate that impairment of phosphodiesterase-4A 5 activity might be one of the crucial events for somatotrophs proliferation in familial cases of acromegaly with AIP mutations.

In conclusion, in a unique investigation based on a health surveillance program in an area of relatively pure exposure to dioxin, we did not find statistically significant increase in the prevalence of pituitary tumors. However, the tendency toward a higher risk of pituitary tumors in subjects exposed to high-intermediate dioxin concentrations in comparison with the nonexposed population strongly indicates the need for extended follow-up.

\section{Declaration of interest}

The authors declare that there is no conflict of interest that would prejudice the impartiality of this scientific work.

\section{Funding}

This work was supported by the regional government of Lombardy within the frame of Environmental Epidemiology Program VIII002306 - 2006-2009.

\section{References}

1 Lania AG, Mantovani G \& Spada A. Mechanisms of disease: mutations of $\mathrm{G}$ proteins and G-protein-coupled receptors in endocrine diseases. Nature Clinical Practice. Endocrinology and Metabolism 20062 681-693.

2 Vierimaa O, Georgitsi M, Lehtonen R, Vahteristo P, Kokko A, Raitila A, Tuppurainen K, Ebeling TM, Salmela P, Pascke R, Gundogdu S, De Menis E, Makinen MJ, Launoned V, Karhu A \& Aaltonen LA. Pituitary adenoma predisposition caused by germline mutations in the AIP gene. Science $20063121228-1230$.

3 Leontiou CA, Gueorguiev M, van der Spuy J, Quinton R, Lolli F, Hassan S, Chahal HS, Igreja SC, Jordan S, Rowe J, Stolbrink M, Christian HC, Wray J, Bishop-Bailey D, Berney DM, Wass JA, Popovic V, Ribeiro-Oliveira A Jr, Gadelha MR, Monson JP, Akker SA, Davis JR, Clayton RN, Yoshimoto K, Iwata T, Matsuno A, Eguchi K, Musat M, Flanagan D, Peters G, Bolger GB, Chapple JP, Frohman LA, Grossman AB \& Korbonits M. The role of the aryl hydrocarbon receptor-interacting protein gene in familial and sporadic pituitary adenomas. Journal of Clinical Endocrinology and Metabolism 200893 2390-2401.

4 Daly AF, Vanbellinghen JF, Khoo SK, Jaffrain-Rea ML, Naves LA, Guitelman MA, Murat A, Emy P, Gimenez-Roqueplo AP, Tamburrano G, Raverot G, Barlier A, De Herder W, Penfornis A, Ciccarelli E, Estour B, Lecompte P, Gatta B, Chabre O, Sabaté MI, Bertagna X, Garcia Basavilbaso N, Stalldecker G, Colao A, Ferolla P, Wémeau JL, Caron P, Sadoul JL, Oneto A, Archambeaud F, Calendar A, Sinilsikova O, Montanana CF, Cavagnini F, Hana V, Solano A, Delettieres D, Luccio-Camelo DC, Basso A, Rohmer V, Brue T, Bours V, Teh BT \& Beckers A. Aryl hydrocarbon receptorinteracting protein gene mutations in familial isolated pituitary adenomas: analysis in 73 families. Journal of Clinical Endocrinology and Metabolism 200792 1891-1896.

5 Yu R, Bonert V, Saporta I, Raffel LJ \& Melmed S. Aryl hydrocarbon receptor interacting protein variants in sporadic pituitary adenomas. Journal of Clinical Endocrinology and Metabolism 2006 $915126-5129$.

6 Carver LA \& Bradfield CA. Ligand-dependent interaction of the aryl hydrocarbon receptor with a novel immunophilin homolog in vivo. Journal of Biological Chemistry 1997272 11452-11456.

7 Carlson DB \& Perdew GH. A dynamic role for the Ah receptor in cell signaling? Insights from a diverse group of Ah receptor interacting proteins Journal of Biochemical and Molecular Toxicology $200216317-325$.

8 Pollenz RS, Wilson SE \& Dougherty EJ. Role of endogenous XAP2 protein on the localization and nucleocytoplasmic shuttling of the endogenous mouse Ahb-1 receptor in the presence and absence of ligand. Molecular Pharmacology 2006 70 1369-1379.

9 Consonni D, Pesatori AC, Zocchetti C, Sindaco R, Cavalieri D’Oro L, Rubagotti M \& Bertazzi PA. Mortality in a population exposed to dioxin after the Seveso, Italy, accident in 1976: 25 years of followup. American Journal of Epidemiology 2008167 847-858.

10 Bertazzi PA, Consonni D, Bachetti S, Rubagotti M, Baccarelli A, Zocchetti C \& Pesatori AC. Health effects of dioxin exposure: a 20-year mortality study. American Journal of Epidemiology 2001 153 1031-1044. 
11 Pesatori AC, Consonni D, Bachetti S, Zocchetti C, Bonzini M, Baccarelli A \& Bertazzi PA. Short- and long-term morbidity and mortality in the population exposed to dioxin after the 'Seveso accident'. Industrial Health $2003 \mathbf{4 1} 127-138$.

12 Patterson DG Jr, Hampton L, Lapeza CR Jr, Belser WT, Green V. Alexander L \& Needham LL. High-resolution gas-chromatography/high-resolution mass spectrometric analysis of human serum on a whole weight and lipid basis for 2,3,7,8-tetra-chlorodibenzop-dioxin. Analytical Chemistry 198759 2000-2005.

13 Needham LL, Gerthoux PM, Patterson DG Jr, Brambilla P, Turner WE, Beretta C, Pirkle JL, Colombo L, Sampson EJ, Tramacere PL, Signorini S, Meazza L, Carreri V, Jackson RJ \& Mocarelli P. Serum dioxin levels in Seveso, Italy, population in 1976. Teratogenesis, Carcinogenesis, and Mutagenesis 1997-1998 17 225-240.

14 Landi MT, Consonni D, Patterson DG Jr, Needham LL, Lucier G, Brambilla P, Cazzaniga MA, Mocarelli P, Pesatori AC, Bertazzi PA \& Caporaso NE. 2,3,7,8-Tetrachlorodibenzo- $p$-dioxin plasma levels in Seveso 20 years after the accident. Environmental Health Perspectives 1998106 273-277.

15 Baccarelli A, Pesatori AC, Consonni D, Mocarelli P, Patterson DG Jr, Caporaso NE, Bertazzi PA \& Landi MT. Health status and plasma dioxin levels in chloracne cases 20 years after the Seveso, Italy accident. British Journal of Dermatology 2005152 459-465.

16 Steenland K, Bertazzi P, Baccarelli A \& Kogevinas M. Dioxin revisited: developments since the 1997 IARC classification of dioxin as a human carcinogen. Environmental Health Perspectives 2004112 1265-1268.

17 Mocarelli P, Needhman LL, Marocchi A, Patterson DG Jr, Brambilla P, Gerthoux PM, Meazza L \& Carreri V. Serum concentrations of 2,3,7,8-tetrachlorodibenzo-p-dioxin and test results from selected residents of Seveso, Italy. Journal of Toxicology and Environmental Health 199132 357-366.

18 Davis JR, Farrel WE \& Clayton RN. Pituitary tumors. Reproduction $2001121363-371$.

19 Daly AF, Rixhon M, Adam C, Dempegioti A, Tichimorowa MA \& Beckers A. High prevelence of pituitary adenomas: a crosssectional study in the province of Liege, Belgium. Journal of Clinical Endocrinology and Metabolism 200691 4769-4775.

20 Nilsson B, Gustavasson-Kadaka E, Bengtsson BA \& Jonsson B. Pituitary adenomas in Sweden between 1958 and 1991: incidence, survival, and mortality. Journal of Clinical Endocrinology and Metabolism $2000 \mathbf{8 5}$ 1420-1425.

21 de Oliveira SK, Hoffmeister MR, Gambaryan S, Muller-Esterl W, Guimaraes JA \& Smolenski AP. Phosphodiesterase 2A forms a complex with the co-chaperone XAP2 and regulates nuclear translocation of the aryl hydrocarbon receptor. Journal of Biological Chemistry $2007 \mathbf{2 8 2} 13656-13663$.

22 Mantovani G, Bondioni S, Ferrero S, Gamba B, Ferrante E, Peverelli E, Corbetta S, Locatelli M, Rampini P, Beck-Peccoz P, Spada A \& Lania AG. Effect of cyclic adenosine $3^{\prime}, 5^{\prime}$-monophosphate/protein kinase a pathway on markers of cell proliferation in nonfunctioning pituitary adenomas. Journal of Clinical Endocrinology and Metabolism $2005906721-6724$.

Received 9 September 2008

Accepted 10 September 2008 